УДК 352.07(477-21/-22)

DOI: 10.34132/pard2019.04.08

\title{
РОЗВИТОК ОРГАНІВ САМООРГАНІЗАЦЇ̈ НАСЕЛЕННЯ В УКРАЇНІ
}

Лізаковська $\boldsymbol{C}$. В., канд., наук $з$ держ. упр., доцент, викладач Військово-морська академія імені Героїв Вестерплатте м. Гдиня, Польща

Стаття присвячена особливостям функиіонування органів самоорганізації населення на вітчизняному рівні. Розглядаються сучасні практики самоорганізачії жителів територіальних громад для вирімення питань місиевого значення.

Проаналізовано основні аспекти, форми та напрями взаємодії між органами державної влади та організаціями громадянського суспільства на регіональному рівні з точки зору втілення Національної стратегії сприяння розвитку громадянського суспільства в Україні на 2016-2020 роки.

Показано нові можливості та проблеми органів самоорганізації населення у розв 'язанні завдань громади у сфері житлово-комунальних послуг, благоустрою, охорони навколишнього середовища та соціальної допомоги пільговим категоріям громадян.

Наголошується на актуальних ризиках протестної самоорганізаиії громадян на місиевому рівні. 3'ясовано поточний стан комунікачії влади з громадськістю, реагування на протестну активність.

Висвітлено роль сочіальних мереж у контексті взаємодії органів державної влади та органів самоорганізащії населення. Наголошено на актуальних проблемах та ризиках їх застосування. Пропонуються заходи щуодо підвищення ролі органів самоорганізаиї населення у вирішенні питань місцевого значення, зниження радикалізачії конфліктів у прочесі планування житлової забудови територій громад.

Доведено, щз подальше поширення органів самоорганізащії населення в краӥні потребує проведення иілеспрямованої, стратегічно 
виваженої державної політики, постійної масштабної інформаційної роботи, спрямованої на підвищення рівня обізнаності населення про характер, проблеми та досягнення, пов'язані з їх реалізацією як в Україні, так і за ї межами.

Ключові слова: благоустрій, громадська самоорганізачія, громадянське суспільство, державна політика, житлово-комунальні послуги, маніпулятивний вплив, органи державної влади, охорона навколишнього середовища, протестна активність, самоорганізація населення, соціальні мережі, територіальна громада.

Постановка проблеми у загальному вигляді. Важливу роль у розв'язанні проблем місцевого значення відіграють органи самоорганізації населення, завдяки яким мешканці громад здійснюють контроль якості житлово-комунальних послуг, захищають свої інтереси у сфері використання земель та майна громади, покращують стан благоустрою прибудинкових територій, вулиць, парків, проводять заходи 3 охорони навколишнього середовища, надають соціальну допомогу пільговим категоріям громадян, дітям-сиротам та дітям, позбавленим батьківського піклування.

Орган самоорганізації населення (далі - ОCH) - це специфічні утворення, що поєднують у собі риси як органу публічної влади, так і громадської організації. 3 органами публічної влади орган самоорганізації населення пов'язує те, що вони беруть участь у вирішенні питань місцевого значення, а також те, що органи самоорганізації населення здійснюють свої повноваження в межах відповідної території. Органи самоорганізації населення працюють на громадських засадах, їх діяльність базується на засадах добровільності щодо взяття на себе окремих повноважень публічної влади.

Створення державою сприятливих умов діяльності органів самоорганізації населення є однією з важливих складових реформи системи місцевого самоврядування та реалізації державної політики сприяння розвитку громадянського суспільства. Успішність виконання такого завдання залежить, серед іншого, від якості програм органів місцевого самоврядування, спрямованих на покращення взаємодії місцевої влади з ОСН. Успішна взаємодія між органами 
влади та організаціями громадянського суспільства є запорукою якісної державної політики, спрямованої на потреби суспільства, підконтрольність та підзвітність йому, відповідність стратегічним національним інтересам.

У Національній стратегії сприяння розвитку громадянського суспільства в Україні на 2016-2020 роки визнано необхідність підвищення присутності інститутів громадянського суспільства у діяльності органів державної влади та органів місцевого самоврядування задля забезпечення реальної участі населення в управлінні місцевими справами [6].

Метою статті є аналіз діяльності, функціонування органів самоорганізації населення, та перспектив розвитку й удосконалення діяльності цих органів.

Аналіз останніх досліджень та публікацій. Проблемам створення, розвитку та вдосконалення органів самоорганізації населення присвячено праці вітчизняних та зарубіжних науковців: В. Бабич, П. Біленчук, В. Бульба, Н. Діденко, О. Корнієвський, В. Куйбіда, А. Мацокін, А. Меляков, В. Михайлюк, Н. Мішина, О. Молодцов, М. Мягченко, В. Олуйко, О. Онищенко, В. Пархоменко, Н. Пеліванова, В. Рубцов, А. Руденко, О. Сушинський, С. Чугунов, Т. Щербань та ін.

Незважаючи на достатньо велику кількість досліджень із зазначеної тематики, констатуємо відсутність всебічного аналізу існуючих протиріч у сфері законодавчого забезпечення, загроз радикалізації, протестної самоорганізації та подальшого розвитку органів самоорганізації населення в Україні.

Формулювання цілей статті (постановка завдання). У процесі дослідження діяльності ОСН були сформульовані наступні завдання:

- розкрити поняття, призначення і специфіку діяльності ОСН;

- проаналізувати нормативно-правову базу взаємодії органів державної влади і ОСН;

- виявити основні проблеми і небезпеки діяльності ОСН;

- визначити перспективи і напрями розвитку та вдосконалення діяльності ОСН, їх взаємодії з органами місцевої влади. 
Виклад основного матеріалу дослідження. У Енциклопедичному словнику з державного управління наведено трактування терміну ОСН: «Органи самоорганізації населення - громадська представницька форма місцевого самоврядування населення певної мікротериторії для самостійного, під свою відповідальність вирішення питань місцевого значення, виходячи з інтересів населення цієї території, із використанням власних та залучених матеріальних і фінансових ресурсів.

Основними завданнями ОСН є:

- створення умов для участі жителів у вирішенні питань місцевого значення у межах Конституції і законів України;

- задоволення соціальних, культурних, побутових та інших потреб жителів шляхом сприяння у наданні їм відповідних послуг;

- участь у реалізації програм соціально-економічного та культурного розвитку відповідної території.

Місцеві ради можуть делегувати ОСН частину власних повноважень із наданням відповідних фінансів і майна. Сприяючи ефективному здійсненню функцій територіальних громад, ОСН розширюють згідно з принципом субсидіарності соціальну основу самоврядування, забезпечують для жителів можливість реалізувати їхні конституційні права на участь в управлінні державними та громадськими справами, а також створюють умови для соціалізації особистостей, реалізації їх духовного та інтелектуального потенціалу» [21, с. 493-494].

ОСН характеризуються окремими ознаками як органу публічної влади, так і громадської організації, а доцільність їх існування зумовлена двома основними чинниками:

- прагненням забезпечити реальні можливості для розгортання місцевої демократії, залучення членів територіальної громади до безпосередньої участі у вирішенні окремих питань місцевого значення;

- намаганнями вивільнити органи місцевого самоврядування від розгляду питань місцевого значення, що можуть бути успішно вирішені самим населенням шляхом передачі відповідних повноважень, фінансових і матеріальних ресурсів органам самоорганізації населення [7]. 
Науковець Т. Щербань підкреслює важливе значення ОСН як інституту, що забезпечує ефективне використання різних форм прямої демократії та поліпшення якості громадських послуг, що надаються населенню в системі місцевого самоврядування, оскільки вони:

- беруть участь у виконанні публічних функцій, пов' язаних з вирішенням питань місцевого значення. Здійснення публічних функцій, у свою чергу, передбачає наявність в органу самоорганізації населення відповідних повноважень, якими він наділяється місцевою радою, що дає підстави характеризувати їх як владні структури, що мають певні спільні риси з органами місцевого самоврядування;

- як і органи публічної влади, органи самоорганізації населення здійснюють свої функції виключно в межах відповідної території.

Необхідність та доцільність існування ОСН обумовлена двома факторами:

- прагненням створити реальні можливості для розгортання місцевої демократії, залучення членів територіальної громади до безпосередньої участі у вирішенні окремих питань місцевого значення;

- намаганням розвантажити органи місцевого самоврядування від вирішення тих питань місцевого значення, що можуть бути успішно вирішені самим населенням, шляхом передачі відповідних повноважень місцевих рад разом з необхідними фінансовими та матеріальними ресурсами ОСН [19, с. 84-85].

В Україні правовий статус ОСН визначається Конституцією (ст. 140), законами «Про місцеве самоврядування в Україні» [12] та «Про органи самоорганізації населення» [13]. Особливості поточної діяльності ОСН мають регулюватися Положенням про цей орган, затвердженим відповідною радою.

Орган самоорганізації населення - це представницький орган, що створюється жителями, які на законних підставах проживають на території селища, міста або їх частин, для вирішення завдань, передбачених Законом України «Про органи самоорганізації населення». Згідно зі статтею 3 зазначеного Закону основними завданнями ОСН $\epsilon$ :

- створення умов для участі жителів у вирішенні питань місцевого значення в межах Конституції і законів України; 
- задоволення соціальних, культурних, побутових та інших потреб жителів шляхом сприяння у наданні їм відповідних послуг;

- участь у реалізації соціально-економічного, культурного розвитку відповідної території, інших місцевих програм.

Основні завдання органів самоорганізації населення обумовлені завданнями та функціями органів місцевого самоврядування.

Обирати та бути обраними до органу самоорганізації населення можуть жителі, які на законних підставах проживають на відповідній території, а порядок виборів визначається Законом України «Про органи самоорганізації населення».

Законом обумовлені певні обмеження при виборах $\mathrm{OCH}$, що забезпечують свідоме волевиявлення жителів, - цензи:

- осілості - вимога проживати на відповідній території на законних підставах;

- віковий - вимога щодо необхідності досягнення жителем вісімнадцяти років;

- дієздатності - у виборах ОСН не беруть участі жителі, яких визнано судом недієздатними.

Забороняються будь-які обмеження права жителів, які проживають на відповідній території, на участь у відповідному органі самоорганізації населення залежно від їхньої раси, кольору шкіри, політичних, релігійних та інших переконань, статі, етнічного та соціального походження, майнового стану, мовних або інших ознак $[13$, ст. 3$]$.

Організація та діяльність органу самоорганізації населення грунтуються на принципах: законності; гласності; добровільності щодо взяття окремих повноважень сільської, селищної, міської ради; територіальності; виборності; підзвітності, підконтрольності та відповідальності перед відповідними радами; фінансової та організаційної самостійності [13, ст. 5].

Гласність роботи і підзвітність ОСН забезпечується шляхом:

- інформування населення про своє місцезнаходження, час роботи і прийом громадян;

- звітування не рідше одного разу на рік про свою діяльність на зборах жителів за місцем проживання; 
- надання можливості громадянам, які проживають на території дії ОСН, знайомитися з його рішеннями [13, ст. 18].

Організація роботи ОСН здійснюється шляхом проведення засідань, які скликаються його керівником або заступником керівника в міру необхідності, але не рідше одного разу на квартал. Порядок позачергового скликання засідання ОСН визначається Положенням про цей орган. Засідання ОСН є правомочним, якщо в ньому бере участь більше половини його загального складу [13, ст. 19].

Орган самоорганізації населення 3 питань, віднесених до його повноважень, може приймати рішення організаційно-розпорядчого характеру. Рішення вважається прийнятим, якщо за нього проголосувало більше половини загального складу цього органу.

Рішення ОСН, що не відповідають чинному законодавству або прийняті з питань, не віднесених до його повноважень, зупиняються відповідною сільською, селищною, міською радою з одночасним зверненням до суду про скасування такого рішення [13, ст. 20].

О. Онищенко звертає увагу на відмінності ОСН і органів державної влади та органів місцевого самоврядування: йдеться про статус органів самоорганізації населення, які не є органами влади, хоча й можуть отримувати від місцевих рад на певний період деякі 3 їх повноважень (делеговані повноваження). 3 іншого боку, судячи 3 підпорядкованого статусу ОСН, оскільки їх створення та легалізація пов'язані $з$ дозвільною діяльністю органів місцевого самоврядування, їх важко віднести й до громадських організацій, хоча вони безпосередньо обираються зборами жителів за місцем проживання. Крім того, можна виділити:

- похідний характер ОСН від органів місцевого самоврядування;

- локально-територіальний масштаб ОСН;

- відсутність єдиної ієрархічної системи ОСН, на відміну від системи органів державної влади.

Такий статус ОСН дозволяє створити можливість для залучення громадян до безпосередньої участі у вирішенні окремих питань місцевого значення, а також перекласти на них ту частку функцій органів місцевого самоврядування, що можуть бути успішно вирішені самим населенням [7, с. 45-46]. 
Щодо особливостей сучасного спрямування діяльності ОСН 3 місцевого розвитку фахівці зазначають збільшення користі від цього органу при вирішенні питань місцевого розвитку. У реальній практиці ОСН вирішуються питання:

- внесення у встановленому порядку пропозицій до проектів місцевих програм соціально-економічного і культурного розвитку відповідних адміністративно-територіальних одиниць, проектів місцевих бюджетів;

- визначення разом із депутатами місцевих рад пріоритетів у використанні коштів 3 депутатського фонду на допомогу виборцям;

- участі у плануванні забудови територій;

- здійснення контролю за якістю надаваних громадянам житлово-комунальних послуг та проведених ремонтних робіт;

- лобіювання перед місцевою владою надання соціальної допомоги мешканцям, введення нових чи відміни наявних транспортних маршрутів, відкриття шкіл, дитячих садків, молодіжних клубів, спортивних секцій, нових магазинів, ремонту та реконструкції комунальних мереж або будинків, благоустрою територій, проведення свят, публічних акцій та інше [7, с. 47].

Складною і невирішеною проблемою у діяльності ОСН Т. Щербань вважає взаємовідносини різних видів органів самоорганізації населення, які співіснують на одній території. Фахівець пропонує створити певну ієрархію органів самоорганізації населення, де б будинкові, вуличні, квартальні комітети були підпорядковані комітету мікрорайону, чисельність жителів якого перевищує 20 тисяч, оскільки великою територією важко управляти, не маючи своїх представників на місцях. Але така ієрархія ОСН суперечить принципам організації та діяльності, передбачених ст. 5 Закону України «Про органи самоорганізації населення», зі змісту якої випливає, що органи самоорганізації населення не можуть бути підпорядковані одне одному [19, с. 90].

Наявні суттєві чинники, що гальмують розвиток ОСН.

О. Онищенко пропонує розглядати проблему системно, згрупувавши виявлені негативні фактори наступним чином: ціннісні (ідеологічні), політичні, інституційні, функціональні. 
До чинників ціннісного рівня, що гальмують розвиток ОСН у країні, віднесено:

- діючу пострадянську парадигму розвитку ОСН як допоміжних структур влади;

- низький рівень їх правової та менеджерської культури;

- недостатню поінформованість населення про місце і роль ОСН у місцевому розвитку.

До чинників політичного рівня, що уповільнюють розвиток ОCН, належать:

- несформованість стабільної системи державної влади;

- правова та інституційна незавершеність розбудови системи місцевого самоврядування;

- розбіжність у поглядах політичних сил на необхідність децентралізації та деконцентрації державної влади;

- невизначеність щодо підвищення ролі та матеріальних можливостей органів місцевого самоврядування стосовно вирішення питань місцевого значення;

- відсутність за сучасної пропорційної виборчої системи безпосередньої зацікавленості кандидатів у депутати у розвитку $\mathrm{OCH}$.

До чинників інституційного рівня, що стримують розвиток ОСН у країні, віднесено:

- дуалізм місця ОСН у системі місцевого самоврядування як представницького органу на своїй території та форми громадської участі населення у вирішенні питань місцевого значення;

- законодавчу невизначеність делегованих ним повноважень, що фактично приводить до визначення меж їх дій за домовленістю 3 місцевими радами;

- безпосередню залежність розвитку сфери діяльності ОСН від зацікавленості, ініціативності та активності місцевої влади.

До чинників функціонального рівня, що перешкоджають розвитку ОСН, віднесено:

- низький рівень фінансування діяльності ОСН;

- незадовільні кадрове забезпечення та стан управління персоналом; 
- неефективну реалізацію підготовки, перепідготовки та підвищення кваліфікації кадрів для такої роботи [7, с. 91-92].

Сучасні дослідження виявили низку проблем та перешкод, що заважають посиленню ролі цих органів та позитивному впливу їх діяльності на соціально-економічний розвиток столиці. 3 метою проведення системного аналізу існуючі проблеми класифіковано як внутрішні і зовнішні.

До зовнішніх проблем і перешкод віднесено: невизначеність статусу ОСН; недосконалість Закону України «Про органи самоорганізації населення», відсутність місцевих нормативно-правових актів, що регулюють процеси створення та діяльності ОСН на території міста; проблема співіснування ОСН різного рівня на одній території (квартальні, вуличні, будинкові); невизначеність принципів та порядку делегування повноважень ОСН міською радою; відсутність механізму виконання рішень ОСН; невизначеність підстав та форм фінансування і матеріально-технічного забезпечення діяльності ОСН; відсутність чіткої уяви у керівництва органів місцевого самоврядування про необхідність розвитку системи ОСН, стратегії, чітких цілей і завдань такого розвитку; відсутність дієвого механізму широкого залучення ОСН органами місцевого самоврядування міста до вирішення гострих проблем локальних громад; відсутність налагодженої системи «зворотного зв'язку» між ОСН як представниками локальних громад та міською владою.

Внутрішні проблеми і перешкоди: відсутність у громадян сформованої потреби у створенні та розвитку ОСН на своїх локальних територіях; неінформованість широких верств населення щодо можливостей та механізму створення $\mathrm{OCH}$; сумнівна легітимність організації та діяльності існуючих ОСН; відсутня чи дуже низька кваліфікація керівництва ОСН, неможливість системно іï підвищувати; недостатній авторитет ОСН та його керівництва серед широкого кола мешканців, що проживають на відповідній території його діяльності; відсутність стратегій і тактик розвитку ОСН, якісних та реалістичних програм розвитку відповідних територій; неспроможність більшості ОСН самостійно залучати фінансові та матеріальні ресурси $[5 ; 7$, с. 92]. 
Таким чином, існуючі невирішені проблеми та перешкоди у діяльності ОСН в Україні призводять до негативних наслідків - протестів населення. Протестна активність є своєрідним індикатором діяльності чи бездіяльності органів влади, бажання чути громадян на місцях, іти на діалог.

Національним інститутом стратегічних досліджень (НICC) опрацьовано дані обласних державних адміністрацій та Київської міської державної адміністрації і сформульовано висновок, що рівень протестної активності у регіонах загалом характеризується як середній.

Основні причини акцій протесту мають переважно соціальноекономічний характер, зокрема:

- підвищення тарифів на житлово-комунальні послуги та оплату в громадському транспорті - в цілому для всіх регіонів;

- земельні питання, у тому числі виділення землі учасникам ATO;

- заборгованість заробітної плати;

- проблеми реалізації соціальних пільг учасників АТО та членів їх сімей, а також житлові проблеми переселенців;

- вимоги відновлення фінансування соціальних пільг та виплат ліквідаторам та постраждалим внаслідок аварії на Чорнобильській AEC;

- питання нелегального видобутку бурштину;

- проблеми власників автомобілів з іноземною реєстрацією [10].

В Аналітичній записці НІСС, підготовленій Н. Пелівановою, визначено особливості протестної самоорганізації на місцевому рівні:

- підштовхують громадян до активної участі в різноманітних протестних акціях слабкість та низький вплив ОСН на місцеву владу у процесі підготовки та прийняття рішень, зростання корупційних ризиків унаслідок розширення повноважень місцевих органів влади;

- провокують ситуації, коли органи місцевої влади обходять процедури громадської участі при здійсненні повноважень у сфері містобудування та використання земель територіальних громад; 
- населення обурює лояльність органів державної та місцевої влади до безконтрольного надання земельних ділянок та їх самозахоплення релігійними громадами.

Підкреслено, що неефективність інституційних механізмів відстоювання інтересів та прав громадян створює небезпечний для місцевої демократії формат вирішення конфліктів, за яким активна громадськість взагалі відмовляється від легальних способів.

Констатується: широкого розповсюдження набула практика блокування доріг, до якої жителі громад, як правило, вдаються за відсутності реакції місцевої влади на їх звернення.

Отже, Н. Пеліванова стверджує, що на місцевому рівні зростає радикалізація соціального протесту, що, у свою чергу, зумовлено суттєвим падінням відповідальності обраних органів місцевого самоврядування перед громадянами [11].

Актуальне і досить складне завдання держави - виявити перспективи та ефективні форми і методи взаємодії органів державної влади з ОСН, створити сприятливі умови діяльності органів самоорганізації населення - $є$ однією 3 важливих складових реформи системи місцевого самоврядування [5].

Успішність виконання такого завдання, як зазначено у звіті Відділу стратегій розвитку громадянського суспільства НІСС, залежить значною мірою від якості програм органів місцевого самоврядування, спрямованих на покращення взаємодії місцевої влади з ОСН [4].

Змістовні, виважені й обгрунтовані Програми розвитку ОСН ухвалено, зокрема, у Бахмуті [15], Вінниці [16], Закарпатській обл. [17], Києві [3], Миколаївській обл. [18], Одесі [2], Сумах [14].

Аналіз змісту зазначених програм дозволяє виокремити такі загальні особливості: широкий спектр напрямів підтримки ОСН; підвищення ролі ОСН у вирішенні питань місцевого значення; визначення обсягів та напрямів бюджетного фінансування місцевих програм; організація контролю за їх виконанням [4].

Наприклад, головною метою Програми розвитку органів самоорганізації населення міста Вінниці на 2017-2021 роки є створення організаційно-правових і матеріально-технічних умов для подальшого розширення участі населення міста у вирішенні завдань його 
соціально-економічного та культурного розвитку і, в першу чергу, більш повного задоволення потреб та інтересів жителів приватного сектору шляхом об'єднання зусиль Вінницької міської ради та ії виконавчих органів з органами самоорганізації населення міста [16].

Отже, аналіз стану співпраці ОСН з органами місцевої влади дозволяє виокремити наступні форми такої взаємодії:

- включення ОСН у вирішення пріоритетних проблем громад 3 використанням механізму соціального замовлення;

- залучення на конкурсній основі ОСН як виконавців соціальних проектів дозволяє місцевим радам ефективніше вирішувати такі завдання, як соціальний захист інвалідів, боротьба із бездомністю, дитячою безпритульністю та бездоглядністю, профілактика СНІДу, ВІЛ-інфекції та наркоманії, захист та покращення стану навколишнього середовища і навіть розвиток туризму;

- делегування місцевими радами органам самоорганізації населення додаткових повноважень;

- вироблення місцевими радами стратегій розвитку ОСН [7, с. $59 ; 8]$.

Відносно новим, перспективним та ефективним засобом громадської самоорганізації в сучасній Україні виявилися соціальні мережі. Щодо ролі соціальних мереж у контексті взаємодії органів державної влади та громадськості існують протилежні судження. У дослідженні НІСС наголошено на актуальних проблемах та ризиках їх застосування. Виокремлено основні форми громадської самоорганізації у Facebook (на 01.01.2018 р. налічувалось 11 млн. користувачів - мешканців України) як найбільш популярної сьогодні платформи. Активно використовують українці також платформи обміну повідомленнями Twitter, Instagram, Viber, WhatsApp, Skype, Telegram тощо.

Станом на січень 2018 року в Україні 58 \% населення користуються Інтернетом (23 млн осіб), 29 \% - соціальними мережами (13 млн).

Важливо підкреслити тенденцію: за 2017 рік кількість українських користувачів соціальних мереж зросла на $67 \%$.

Основними причинами стрімкого зростання популярності соціальних мереж, окрім очевидної зручності їх використання, $є$ й той 
безперечний факт, що соціальні мережі як джерело інформації мають значний рівень довіри населення. За даними дослідження, наприкінці 2017 року соціальним мережам довіряли 37 \% українців $[5$, c. 2].

Соціальні мережі дедалі більше стають певною мірою інформаційним відбитком громадянської активності, оскільки саме цей канал комунікації використовується для поширення ідей, об'єднання однодумців у спільноти, організації заходів, координації зусиль. Практично всі суспільно значущі процеси, події, явища залишають певний інформаційний відбиток у соціальних мережах [5, с. 3].

Відносно використання соціальних мереж у діяльності громадських організацій варто зазначити, що вони займають перше місце серед електронних інструментів, які використовують у своїй діяльності ОСН. До переваг соціальних мереж відносять:

- кращу прозорість управління і підзвітність організацій - надають інформацію про витрачені кошти;

- можливість організаціям безпосередньо взаємодіяти 3 аудиторіями: PR, інформування про організацію, iіi місію, досягнення, поширення важливої інформації;

- швидкість поширення своєчасної інформації (актуальні анонси, збір коштів);

- прозорість публічного обговорення і вирішення локальних проблем (забудови, прибирання), пропагування ідей;

- можливість створити високочутливе громадянське суспільство;

- соціальні мережі дозволяють організаціям залучити групи населення, увагу яких важко привернути за допомогою традиційних засобів масової інформації [5, с. 6-7].

3 іншого боку, існують проблеми та ризики застосування соціальних мереж. Цілком очевидним є той факт, що використання соціальних мереж у громадському секторі, окрім багатьох переваг, має певні ризики, оскільки вони:

- впливають на громадську думку, використовуються як мобілізаційний засіб у протестних акціях 3 метою залучення масової підтримки; 
- як середовище здійснення впливу на свідомість населення в умовах недостатньо сформованої інформаційної культури населення підсилюють можливості маніпулятивного впливу на користувачів;

- сприяють замовному характеру роботи «лідерів думок», цілеспрямованій дезінформації, що практикується в українському інформаційному просторі.

Отже, з одного боку, можливості інформаційно-комунікаційних технологій дозволяють залучати широке коло громадян до вирішення певних проблем чи акцентування на них уваги, а $з$ іншого - $€$ ризик того, що вони можуть використовуватися як мобілізаційний засіб у протестних акціях задля маніпулятивного впливу та цілеспрямованої дезінформації [5, с. 12-14].

Таким чином, подальше вдосконалення діяльності ОСН базується на нових тенденціях їх розвитку, зокрема:

- розуміння їх частиною населення як громадської організації, яка частково дублює повноваження органів місцевого самоврядування;

- здійснення їх політизації, фіктивність створення;

- обрання службовців місцевого самоврядування через комітети самоорганізації;

- робота комітетів на громадських засадах;

- організація перешкод у створенні комітетів самоорганізаціі;

- контроль за діяльністю об'єднань співвласників багатоквартирних будинків;

- голова комітету самоорганізації міста $є$ альтернативою міським депутатам;

- активізація професіоналів у створенні та розвитку комітетів самоорганізації населення.

Висновки. Активна діяльність органів самоорганізації населення сприяє адаптації громадян до умов децентралізації, дозволяє вирішувати важливі питання місцевого розвитку швидко та ефективно, узгоджувати різні, навіть протилежні, інтереси членів громад.

Особливістю органу самоорганізації населення є його статус, за яким ОСН не є органом влади, хоча й може отримувати від місце- 
вої ради деякі делеговані нею повноваження. ОСН також не можна віднести до громадських організацій, хоча він безпосередньо обирається зборами жителів за місцем проживання. Саме такий його реальний статус надає потенційні можливості залучити широкий спектр докладання зусиль у напрямку розвитку територіальних громад.

Найбільш ефективно ОСН розв'язують місцеві проблеми у тих територіальних громадах, де органи місцевого самоврядування оперативно ухвалюють статути, власні програми сприяння розвитку $\mathrm{OCH}$, активно залучають їх до виконання цільових програм, творчо впроваджують механізми соціального замовлення та співфінансування проектів з розвитку територій громад.

Виявлені недосконалість законодавства щодо діяльності ОСН та їх взаємодії з органами місцевої влади, низькі якість планування та використання місцевих бюджетів, слабка відповідальність та відсутність належного зв' язку між громадянами та органами місцевого самоврядування призводять до поширення протестних настроїв та загрожують радикалізацією окремих представників місцевих громад.

Сьогодні ставлення громадян до ОСН є неоднозначним. Для успішного розвитку системи ОСН необхідно забезпечити більш високий рівень їх підтримки населенням, що безпосередньо пов'язано з більшою зацікавленістю громадян у таких органах. Тому запорукою громадської підтримки діяльності ОСН є надання ними все більш реальної користі населенню.

Подальше поширення органів самоорганізації населення вимагає проведення цілеспрямованої, виваженої державної політики, постійної масштабної інформаційної роботи, спрямованої на підвищення рівня обізнаності населення про характер, проблеми та досягнення ОСН.

Стаття надійшла до редакції: 17.03.2019 


\section{DEVELOPMENT OF POPULATION SELF-ORGANIZATION BODIES}

Svitlana Lizakowska, $\mathrm{PhD}$ in Public Administration, Associate Professor of the Department Polish Naval Academy, str. Inżyniera Jana Śmidowicza 69, Gdynia, 81-103, Poland.

The article is devoted to the study of the peculiarities of population self-organization bodies at the executive bodies. The contemporary practices within civil self-organization of local communities for solving local issues are considered.

The main aspects, forms and directions of interaction between public authorities and civil society organizations at the regional level as to the implementation of the National Strategy for Promoting the Civil Society Development in Ukraine for 2016-2020 are explored.

The new possibilities and issues of population self-organization bodies at solving community problems within the sphere of housing and communal services, improvement, environmental protection and social assistance to preferential categories of citizens are analyzed.

The actual risks of protest citizen self-organization at the local terms are emphasized. The current state of communication between authorities and the public, reaction to protest activity is revealed.

The role of social networks in the context of interaction between public authorities and the public is analyzed. The actual problems and risks of their application are emphasized. Measures to increase the role of population self-organization bodies at solving local issues, reducing the radicalization of conflicts in the process of planning the housing development of community territories are proposed.

It is proved that the further spread of population self-organization bodies in the state requires a purposeful, strategically balanced state policy, a constant large-scale informational activity aimed at increasing the awareness of the population about the nature, problems and achievements associated with their implementation either in Ukraine or abroad.

The peculiarity of a population self-organization body (further PSB) is its status, according to which this is not an authority, although it 
may receive some delegated powers from the local council. PSBs cannot be attributed to civic organizations, although they are directly elected by residential gatherings. It is this real status of PSBs that offers potential opportunities to attract a wide range of efforts thereto.

There have been revealed the imperfection of legislation as to the PSB activity and their interaction with local authorities, low quality planning and the discipline of local budgets use, low responsibility and lack of proper communication between citizens and elected local authorities leads to the spread of protest moods and threatens to bring the radicalization of individual representatives within local communities.

Further spread of PSBs requires a focused, well-balanced state policy, a constant large-scale informational activity aimed at raising public awareness of the nature, problems and achievements associated with their implementation in Ukraine.

Keywords: improvement, public self-organization, civil society, state policy, housing and communal services, manipulative influence, state authorities, environmental protection, protest activity, population self-organization, social networks, local community.

\section{Received: 17.03.2019}

\section{References}

1. Bulba V., \& Meliakov A. Analiz diialnosti orhaniv samovriaduvannia v Ukraini [Analysis of Self-Government Bodies' Activity in Ukraine.] Retrieved from http://www.dridu.dp.ua/vidavnictvo/2011/2011_01(8)/ 11bvgsnu.pdf

2. Miska tsilova Prohrama rozvytku orhaniv samoorhanizatsii naselennia v m. Odesi na 2016-2019 roky [Urban Target Program for the Development of Population Self-Organization Bodies in Odesa City for 2016-2019] Retrieved from https://omr.gov.ua/ru/acts/council/78744/

3. Miska tsilova prohrama «Spryiannia rozvytku hromadianskoho suspilstva u m. Kyievi na 2017-2019 rr.» [Urban Target Program Promoting of the Civil Society Development in Kyiv City for 2017-2019] Retrieved from http://kmr.ligazakon.ua/SITE2/1_docki2.nsf/alldocWWW/DAD116B508DA1E 09C225809E006E0C4B?OpenDocument 
4. Mistsevi prohramy spryiannia rozvytku orhaniv samoorhanizatsii naselennia: dosvid ukhvalennia ta realizatsii. Analitychna zapyska [Local Programs for the Promotion of the Population Self-Organization Bodies' Development: The Experience of Adoption and Implementation. Analytical Note] Retrieved from http://www.niss.gov.ua/articles/1356/

5. Mykhailiuk V. Efektyvnist diialnosti orhaniv mistsevoho samovriaduvannia yak zaporuka nadannia yakisnykh posluh naselenniu [Effectiveness of Local Self-Government Bodies as a Guarantee of Providing Quality Services to the Population] Retrieved from http://intkonf.org/ mihaylyuk-vs-efektivnist-diyalnosti-organiv-mistsevogo-samovryaduvannyayak-zaporuka-nadannya-yakisnih-poslug-naselennyu/

6. Natsionalna stratehiia spryiannia rozvytku hromadianskoho suspilstva v Ukraini na 2016-2020 roky / Ukaz Prezydenta Ukrainy vid 26 liutoho 2016 roku \# 68/2016. Uriadovyi kurier ot 02.03.2016, \# 41[National Strategy for Promoting the Development of Civil Society in Ukraine for 2016-2020 / Decree of the President of Ukraine dated 26.02.2016 No. 68/2016 // Uriadovyi Courier dated 02.03.2016, No. 41] [in Ukrainian].

7. Onyshchenko O.V. (2015) Diialnist orhaniv samoorhanizatsii naselennia yak instrument sotsialno-ekonomichnoho rozvytku terytorii (na prykladi m. Kyieva) [Activity of Population Self-Organization Bodies as an Instrument of Socio-Economic Development at the Territories (Kyiv City as an example)] Kyiv: NADU [in Ukrainian].

8. Orhanizatsiia roboty orhaniv samoorhanizatsii naselennia / Derzhavne budivnytstvo ta mistseve samovriaduvannia [Organization of Activity within Population Self-Organization Bodies/State Building and Local Self-Government] Retrieved from http://radnuk.info/pidrychnuku/482-bydivnutstvo/8892-s-7html

9. Orhany samoorhanizatsii naselennia [Population Self-Organization Bodies] Retrieved from http://yurist-online.com/ukr/uslugi/yuristam/literatura/ dergh_bud/ 91.php

10. Osnovni formy ta napriamy vzaiemodii orhaniv derzhavnoi vlady $z$ orhanizatsiiamy hromadianskoho suspilstva v Ukraini na rehionalnomu rivni. Analitychna zapyska [The Main Forms and Directions of Cooperation between Public Authorities and Civil Society Organizations in Ukraine at the Regional Level. Analytical Note] Retrieved from http://www.niss.gov.ua/content/articles/ files/Rudenko_region-0c8fe.pdf

11. Postmaidanni praktyky samoorhanizatsii hromadian ukrainy $u$ vyrishenni pytan mistsevoho znachennia. Analitychna zapyska [Post-Maidan Practices of Self-Organization among Ukrainian Citizens in Solving Local 
Issues. Analytical Note] Retrieved from http://www.niss.gov.ua/content/articles/ files/1_Pelivanova-06.2018-ddb84.pdf

12. Pro mistseve samovriaduvannia / Zakon Ukrainy \# 280/97-VR vid 21 travnia 1997 roku [On Local Self-Government / Law of Ukraine No. 280/97-VR dated 21.05.1997 // Verkhovna Rada of Ukraine, 2008, No. 48] VVR Ukrainy, 2008, \# 48 [in Ukrainian].

13. Pro orhany samoorhanizatsii naselennia / Zakon Ukrainy \# 2625-III vid 30.11.2001 // VVR Ukrainy, 2001 r., \# 48, stattia 254 [On Population SelfOrganization Bodies / Law of Ukraine No. 2625-III dated 30.11.2001 // Office of Verkhovna Rada of Ukraine, 2001, No. 48, Article 254] [in Ukrainian].

14. Prohrama ekonomichnoho i sotsialnoho rozvytku m. Sumy na 2019 rik ta osnovni napriamy rozvytku na 2020-2021 roky [Social and Economic Development Program of Sumy City for 2019 and the Main Directions in the Development for 2020 - 2021] Retrieved from https://smr.gov.ua/uk/ dokumenti/ ekonomichnij-i-sotsialnij-stan-mista.html

15. Prohrama rozvytku orhaniv samoorhanizatsii naselennia m. Bakhmuta na 2016-2020 roky [Program of Population Self-Organization Bodies' Development in Bakhmut Town for 2016-2020] Retrieved from http://artemrada. gov.ua/11573

16. Prohrama rozvytku orhaniv samoorhanizatsii naselennia m. Vinnytsi na 2017-2021 roky [The Program of Population Self-Organization Bodies' Development in Vinnytsia City for 2017-2021] Retrieved from http://www. vmr.gov.ua/municipalenreprise/lists/populationselforganizationassociation/ showcontent.aspx?id $=6$

17. Prohramy sotsialno-ekonomichnoho rozvytku Zakarpastkoi oblasti [Social and Economic Development Programmes of Zakarpattia Region] Retrieved from https://carpathia.gov.ua/storinka regionalni-programy-rozvytku

18. Rozvytok orhaniv samoorhanizatsii naselennia u mistakh ta selakh Mykolaivshchyni [Population Self-Organization Bodies' Development in Cities and Villages of Mykolaiv Region] Retrieved from http://www.frgn.mk.ua/wpcontent/uploads/2014/02/broshura\%20OSN.pdf

19. Shcherban T.Pidvyshchennia znachennia ta roli orhaniv samoorhanizatsii naselennia $\mathrm{v}$ systemi mistsevoho samovriaduvannia [Increasing the Value and Role of Population Self-Organization Bodies in the System of Local SelfGovernment] Retrieved from http://www.cvk.gov.ua/visnyk/pdf/2008_2/ visnik_st_19.pdf

20. Sotsialni merezhi yak efektyvnyi zasib hromadskoi samoorhanizatsii v suchasnii Ukraini. Analitychna zapyska [Social Networks as an Effective Means 
of Civil Self-Organization in Contemporary Ukraine. Analytical Note] Retrieved from http:/www.niss.gov.ua/content/articles/files/Rudenko-52ea7.pdf

21. Surmin Yu. P., \& Bakumenko V. D., \& Mihnenko A. M. (2010) Enciklopedichnij slovnik z derzhavnogo upravlinnya [Encyclopaedic Dictionary of Public Management] Kyiv: NADU [in Ukrainian].

\section{Відомості про авторів / Information about the Author}

Лізаковська Світлана Володимирівна: Військово-морська академія ім. Героїв Вестерплатте, вул. Шмідовіча 69, Гдиня, 81-103, Республіка Польща.

Svitlana Lizakowska: Polish Naval Academy, str. Inżyniera Jana Śmidowicza 69, Gdynia, 81-103, Poland.

ORCID.ORG/0000-0002-1524-2673

E-mail: svema84@mail.ru 